\title{
Evaluating the Bystander Effects of Electron Beam Irradiation in Radiotherapy on MCF-7 Human Breast Cancer Cells
}

\author{
Maryam Feghhi \\ Urmia University of Medical Sciences \\ Jafar Rezaie \\ Urmia University of Medical Sciences \\ Kamal Mostafanezhad \\ Urmia University of Medical Sciences \\ Nasrollah Jabbari ( $\nabla$ njabbarimp@gmail.com ) \\ Urmia University of Medical Sciences
}

\section{Research Article}

Keywords: Electron beam, Breast cancer, MCF-7, Bystander effects, Conditioned media

Posted Date: December 3rd, 2019

DOI: https://doi.org/10.21203/rs.2.17986/v1

License: @ (i) This work is licensed under a Creative Commons Attribution 4.0 International License.

Read Full License 


\section{Abstract}

Background: The distinct direct and non-targeting effects of electron beam radiation on MCF-7 cells remain unclear. We aimed to investigate the effect of electron beam radiation and conditioned media of the irradiated MCF-7 cells on MCF-7 cells.

Methods: The cell viability and apoptosis were assayed via MTT and flow cytometry analysis, respectively. Production of oxygen reactive species was evaluated by chemical fluorometric method, while the amount of extracellular vesicles was detected via acetylcholinesterase activity assay. Change in the expression of genes involved in apoptosis including caspase-3, caspase-8, and caspase- 9 and stemness such as Sox-2 and Oct-4 were calculated through qPCR. Wound healing rate of cells was monitored via in vitro scratch assy.

Results: Result showed that compared to control group, electron beam radiation decreased cell viability and increased apoptosis and oxygen reactive species as well as acetylcholinesterase activity in a dosedependent manner $(P<0.05)$. Concurrent with increasing dose of electron beam, the mRNA level of apoptotic genes (caspase-3, caspase-8, and caspase-9) and stemness related genes (Sox-2 and Oct-4) up-regulated following electron beam radiation. Wound healing rate of irradiated MCF-7 cells dosedependently increased $(P<0.05)$. After treatment with conditioned media from irradiated MCF-7 cells, the similar results were observed. Conditioned media from irradiated MCF-7 cells decreased viability of MCF7 cells, mesenchymal stem cells, and HUVECs $(P<0.05)$. Additionally, conditioned media from irradiated MCF-7 cells promoted apoptosis and wound healing rate as well as increased mRNA levels of apoptosis and stemness related genes $(P<0.05)$.

Conclusion: Findings suggest electron beam radiation could affect apoptosis and stemness in MCF-7 cells in direct and bystander manners.

\section{Background}

Breast malignancy is raised from breast tissue which has hold a great concern due to high rate of incidence and mortality worldwide [1]. This cancer remains the challenging due to resistance to different treatments [2]. Traditionally, different methods such as surgery, chemotherapy, hormonal therapy, and radiation therapy have been exploited by physician to eliminated tumor cells [3, 4]. One of the well-known treatments for breast cancer is radiation therapy, which ionizing radiation (IR) directly destroys cancer cells [5]. Intraoperative radiation therapy (IORT) is more effective method in reduction of local recurrence than the standard external beam radiotherapy of whole breast [6, 7]. IORT is a method of directly irradiation of operated area during surgery which delivers increasing dose of radiation on operated area [8]. This method is an alternative to 6 weeks of external beam radiotherapy, which is equal to the deliverance of electron beam called intraoperative electron radiotherapy (IOERT) or 50-kv X-ray to tumor region during breast conserving surgery $[9,10]$. 
IOERT has been considered to improve treatment of breast cancer and prevent local recurrences of it after surgery in breast conserving therapy $[8,9]$. Indeed, electron beam therapy is a kind of radiation treatment that electrons are directed to a tumor site instead of photons. It is well established that electron beam damage bio-molecules and organelles of tumor cells, contributing in eliminating tumor cells [11, 12]. Growing evidence reported that cells dwelled in tumor mass may indirectly were affected by IR, which previously known as non-targeting effects (NTEs) of radiation [13]. Bystander effects are a class of NTEs by which direct irradiated cells influence non-irradiated cells in an irradiated volume [14]. Of note, irradiated cells mediate the bystander effects of IR by releasing various soluble factors including cytokines, reactive oxygen species (ROS), and even exosomes into extracellular matrix that eventually affect fate and function of neighboring non-irradiated cells known as bystander cells [15]. In this regard, signals received from directly IR irradiated cells may induce mutations, DNA damage, apoptosis, chromosomal instability, migration, and resistance in non-irradiated cell $[14,16]$. In recent years, most studies have only focused to assess different responses of tumor cells to IR and to signals from directly irradiated cells [17-19].

Electron beam therapy is especially useful for treatment of superficial tumors. However, the biological and molecular effects of routine electron beam therapy and IOERT on tumor cells and its environment are not reported exactly up to now [10]. In line with these comments, the underling mechanisms involved in MCF-7 cells responses against directly and bystander effects of electron beam exposure need to be evaluated. Here, we aimed to highlight the direct and bystander effects of electron beam treatment on MCF-7 human breast cancer cell line.

\section{Methods}

\section{Cell culture}

Human breast cancer MCF-7 cells (Royan, Iran ), mesenchymal stem cells (MSCs) (Pastor, Iran), and human umbilical vein stem cells (HUVECs) (Pastor, Iran) were cultured in DMEM medium enriched with $10 \%$ fetal bovine serum (FBS, Gibco) and 1\% penicillin-streptomycin (Gibco) and were kept at $37^{\circ} \mathrm{C}$ in a moist atmosphere of $5 \% \mathrm{CO}_{2}$.

\section{Irradiation}

Following a dosimetry calibration, a clinical $5 \mathrm{MeV}$ electron beam of a Siemens PRIMUS medical linear accelerator (Siemens AG, Germany) was used for irradiation. The output of machine is calibrated such that 1.0 monitor unit (MU) is equal to $1.0 \mathrm{cGy}$. MCF-7 cells were seeded in 96 and 6-well plates $24 \mathrm{~h}$ prior to irradiation in order to measure cell viability using MTT assay and other tests, respectively. Medium level was adjusted to $11 \mathrm{~mm}$ over the cell monolayer to place the MCF-7 cells at the depth of maximum dose $\left(d_{\max }\right)$. A standard electron applicator $\left(25 \times 25 \mathrm{~cm}^{2}\right)$ was placed on the accelerator head for irradiation. The cells in the plates were positioned at $100 \mathrm{~cm}$ distance from the electron source, and irradiation was done at an output rate of $300 \mathrm{MU} / \mathrm{min}$. The cell culture plates were placed at the center of 
the radiation field to ensure that all the cells irradiated with a uniform radiation dose. MCF-7 cells were divided into 5 groups and exposed to 2, 4, 6, 8, 10 Gy of electron beam. The non-irradiated cells were kept as control group and subjected to the same condition as the electron treated cells experienced. The MU values were calculated by taking into account that $1 \mathrm{cGy} / \mathrm{MU}$. After irradiation, the cells were returned to the incubator and maintained under culture condition for $48 \mathrm{~h}$ post-irradiation, prior to evaluation. All biological experiments were repeated in three different series.

\section{Conditioned medium (CM) preparation}

$48 \mathrm{~h}$ after irradiation, CMs of all groups were collected and centrifuged $\left(15,000 \mathrm{~g}\right.$ for 20 min at $\left.4^{\circ} \mathrm{C}\right)$ and $0.2 \mathrm{~mm}$ syringe filters used to remove remained cells and debris. The filtrated cell conditioned medium was saved in $-80 \mathrm{C}$ freezer for next experiments.

\section{Conditioned media treatment}

To investigate bystander effects of irradiated MCF-7 cells, the non-irradiated MCF-7 cells, HUVECs, and MSCs co-cultured with CMs of irradiated and non-irradiated MCF-7 cells (control CM) for a period of $48 \mathrm{~h}$ and kept as bystander cells. According to irradiation protocol, bystander cells are received the $\mathrm{CMs}$ of relevant groups and named as: Control-CM, 2 Gy-CM, 4 Gy-CM, 6 Gy-CM, 8 Gy-CM, and 10 Gy-CM. Additionally, one group was kept as control group which cultured in DMEM/FBS media in the same condition.

\section{Cell viability}

Cell viability was determined $48 \mathrm{~h}$ after irradiation using MTT assay. Prior to irradiation and CMs treatment, $5 \times 10^{3}$ cells seeded in per well of 96 well plates for $24 \mathrm{~h}$. Next, MTT reagent was dissolved at a concentration of $5 \mathrm{mg} / \mathrm{ml}$ in sterile phosphate-buffered saline (PBS) in the dark. $48 \mathrm{~h}$ after irradiation, the cell media removed completely and replaced with $100 \mathrm{ml} /$ well of MTT solution and then incubated for 4 h. After $4 \mathrm{~h}$, wells were depleted and $100 \mathrm{ml}$ of dimethyl sulfoxide (DMSO) added to each well for $20 \mathrm{~min}$ at room temperature. Absorbance was measured using a micro-plate reader at a wavelength of $540 \mathrm{~nm}$. Analysis was accomplished by following formula: (optical density (OD) sample/OD control) $\times 100$.

\section{Flow cytometry analysisof apoptosis}

We used Annexin-V (eBioscience) marker to monitor apoptosis rate in MCF-7 cells. For this purpose, $48 \mathrm{~h}$ after irradiation and incubation with $\mathrm{CMs}$, Cells were subjected to Annexin-V kit protocol according to manufacture recommendation. In brief, cells were fixed with $100 \mathrm{ml}$ of binding buffer at room temperature for $15 \mathrm{~min}$. Next, Annexin- $\mathrm{V}(1 \mathrm{ml} / \mathrm{ml})$ was added to each sample at room temperature over $15 \mathrm{~min}$ in a dark room. Following twice washing with PBS, cells were suspended in the $1 \mathrm{ml}$ final volume of binding buffer. Analysis was performed by a flowcytometric system (BioRad, Hercules, CA, USA) and FlowJo (version 7.6.1) software.

\section{ROS production}


Chemical fluorometric method was used for detection of ROS production using a ROS assay Kit (E-BC$\mathrm{K} 138$, Elabscience). According to kit's protocol, $1 \mathrm{~h}$ after irradiation, $10 \mu \mathrm{M}$ of dichlorofluorescein diacetate (DCFH-DA) reagent was added to cell culture medium and incubated at $37^{\circ}$ Cover $30 \mathrm{~min}$. Then, cell suspensions were centrifuged at $1000 \mathrm{~g}$ for 5 min and washed with PBS twice. Finally, the fluorescence was measured using a micro-plate reader (Bio-Rad) at wavelength of $485 \mathrm{~nm}$ excitation and $525 \mathrm{~nm}$ emission.

\section{Acetylcholinesterase activity assay}

Acetylcholinesterase (AChE) activity was applied to evaluate extracellular vesicles in CMs of MCF-7 cells via cholinesterase kit (Cat No. BXC080; Iran).In brief, solution A (potassium hexacyanoferrateand pyrophosphate) was mixed to CMs and incubated for $5 \mathrm{~min}$ at room temperature. After that, solution $\mathrm{B}$ (2butyrylthio-n,n,n-trimethylethanaminium iodide) was added and the absorbance was detected at $405 \mathrm{~nm}$ by three time points using a plate reader system (BioTek). AChE activity was analyzed by the recommended formula: Activity $(\mathrm{U} / \mathrm{I})=65,800 \times \Delta \mathrm{Abs} / \mathrm{min}$.

\section{Real time-PCR analysis}

In order to analyze expressions of apoptosis genes including caspase-3, 8, and 9 and; Sox-2 and Oct-4 genes dealing with stemness, real time-PCR analysis was used. Total RNA was isolated using RNA extraction kit (Cat.No: FABRK001, Iran). Next, RNA quality and quantity were evaluated using a Nanodrop system (BioTek). cDNA synthesis accomplished by a commercial cDNA synthesis kit (Cat:YT4500, Iran). Next, mRNA levels of genes were measured using SYBR Green dye-based PCR Master Mix (YT2551, Yekta Tajhiz Azma, Iran) and real time-PCR system (ABI 7500, Applied Biosystems). Data were normalized against GAPDH gene and analyzed using the $2^{-\triangle \Delta C t}$ method. The sequences of primers are listed in Table 1.

\section{Wound healing assay}

The MCF-7 cells were cultured in a 12-well plate until they reached $80 \%$ confluence. The cell monolayer was scratched using a yellow tip. Next, the supernatants were replaced by CMs for $48 \mathrm{~h}$. The cell-free scratched area was monitored at $0 \mathrm{~h}$ and $48 \mathrm{~h}$ of incubation and measured using an Image j software ver. $1.44 \mathrm{p}$. Wound healing rate was reported by applying a formula :( first surface area - second surface area)/ first surface area) $\times 100$.

\section{Statistical analysis}

Statistical analyses were accomplished using SPSS software version 25. Results are presented as mean $\pm S D$. The statistical significances betweengroups were calculated using analysis of variance (ANOVA) with a Tukey's honest significance test. In all analysis $P<0.05$ was considered statistically significant. In graphs, brackets represent the significant between

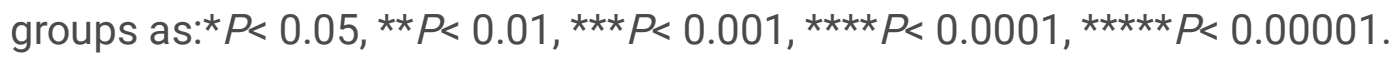




\section{Results}

\section{Cell survival was decreased by electron beam irradiation}

To investigate possible effects of electron beam irradiation (EBI) on MCF-7 cells viability, MTT assay was performed $48 \mathrm{~h}$ post-irradiation. MTT assay showed that irradiation caused significantly decrease in cell viability as compared to control group in a dose-dependent relationship ( $P_{\text {Control vs.4 Gy group }}<0.05 ; P_{\text {Control }}$ vs. 6 Gy and 8 Gy groups $<0.001 ; P_{\text {Control vs. } 10 \text { Gy group }}<0.0001 ;$ Fig. $\left.1 \mathrm{~A}\right)$. The same results were obtained when 2 Gy group compared to 6,8 , and10 Gy groups $\left(P_{2 \text { Gy group vs.6 Gyand } 8 \text { Gy groups }}<0.01 ; P_{2 G y}\right.$ group vs. 10 Gy group $<$ 0.0001 ). Our finding indicated that EBI dose-dependently reduced viability of MCF-7 cells at the end point of $48 \mathrm{~h}$ post-radiation.

\section{Electron beam irradiation enhanced apoptosis rate of MCF-7 cells}

AnnexinV marker was used to monitor apoptosis rate of MCF-7 cells. Data showed a significant increase in apoptosis rate of MCF-7 cells subjected to electron beam in a dose-dependent manner ( $P_{\text {Control vs.4 Gy }}$ group $<0.05$; $P_{\text {Control vs.6 Gy group }}<0.01$; $P_{\text {Control vs. } 8 \text { Gy group }}<0.001 ; P_{\text {Control vs. } 10 \text { Gy group }}<0.00001 ;$ Fig. $\left.1 \mathrm{~B}, \mathrm{C}\right)$. In comparison to $2 \mathrm{~Gy}$ group, percentage of apoptotic cells elevated in other groups ( $P_{2}$ Gy group vs.6 Gy group $<0.05 ; P_{2}$ Gy group vs.8 Gy group $<0.01 ; P_{2}$ Gy group vs. 8 Gy group $\left.<0.0001\right)$. Compared to the 4 Gy group, apoptosis was increased in $8 \mathrm{~Gy}$ and $10 \mathrm{~Gy}$ irradiated cells ( $P<0.05$ and $P<0.001$, respectively). $10 \mathrm{~Gy}$ beam electron caused significantly increase in percentage of apoptotic cells as compared to $6 \mathrm{~Gy}$ $(P<0.01)$, and 8 Gy irradiation $(P<0.01)$ (Fig. 1B, C).

\section{Electron beam irradiation increased ROS production in MCF-7 cells}

Fluorometric method was used to measure ROS production in irradiated cell. Our finding indicated that EBI increased ROS production in MCF-7 cells in a dose-dependent relationship ( $P_{\text {Control vs.2Gy and } 4 \text { Gy }}$ groups $<0.05$; $P_{\text {Control vs. } 6 \text { Gy group }}<0.001$; $P_{\text {Control vs. } 8 \text { Gy and10 Gy group }}<0.000001$; Fig. $\left.2 \mathrm{~A}\right)$. Compared to 2 Gy$\mathrm{CM}$, ROS production amplified in 6Gy, $8 \mathrm{~Gy}$, and $10 \mathrm{~Gy}$ irradiated cells $\left(P_{2}\right.$ Gy group vs.6 Gy group $<0.05 ; P_{2}$

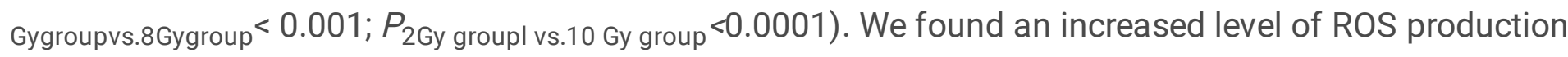
in $8 \mathrm{~Gy}$ and $10 \mathrm{~Gy}$ groups as compared to $4 \mathrm{~Gy}$ group $\left(P_{4}\right.$ Gy group vs. 8 Gy and10 Gy groups $<0.001$ ). In comparison to $6 \mathrm{~Gy}$ irradiation, $10 \mathrm{~Gy}$ irradiation caused a significant increase in ROS production in MCF7 cells $(P<0.01$; Fig. $2 A)$.

\section{Electron beam irradiation increased the AChE activity in conditioned media of MCF-7 cells}

AChE activity, an enzyme associated with extracellular vesicles, used to measure the extracellular vesicles content in CMs. According to data from Fig.2B, high intensity of EBI increased AChE activity as compared to control group ( $P_{\text {Control vs.6 Gy group }}<0.05$; $\left.P_{\text {Control vs.8 and } 10 \text { Gy groups }}<0.01\right)$. Compared with both $2 \mathrm{~Gy}$ and 4 Gy groups, the AChE activity was elevated in 8 Gy and 10 Gy groups ( $P_{2}$ Gy and 4 Gy groups vs. 8 Gy and 10 Gy groups $<0.05$; Fig.2B). 
To further insight into apoptosis, we measured the mRNA level of apoptotic genes by real time-PCR. The application of higher doses of EBI ( 8 Gy and $10 \mathrm{~Gy}$ ) showed an increase in the level of caspase-9 transcript ( $P_{\text {Control and } 2 \text { Gy groups vs. } 8 \text { Gy group }}<0.05$; $P_{\text {Control and } 2 \text { Gy groups vs. } 10 \text { Gy group }}<0.01 ;$ Fig. 3 ). Compared to 4 Gy and 6 Gy groups, the mRNA level of caspase- 9 augmented in 10 Gy group $\left(P_{4 \mathrm{~Gy}}\right.$ and 6 Gy groups vs. 10 Gygroup $<0.05)$.

As shown in Fig. 3, compared to control group, $10 \mathrm{~Gy}$ and $8 \mathrm{GyEBI}$ markedly induced expression of caspase- 8 in MCF-7 cells ( $P<0.05$ and $P<0.01$, respectively). In addition, 10 GyEBI caused a significant increase in mRNA level of caspase-8 as compared to other doses of EBI ( $P_{2}$ Gy and 4 Gy groups vs. 10 Gy group $<$ $0.01 ; P_{6 G y}$ groups vs.10 Gy group $<0.05 ;$ Fig. 3$)$.

Correspondingly, the transcript level of the caspase- 3 , an apoptotic executer, increased in irradiated cells as compared to control group ( $P_{\text {Control vs. } 4 \text { Gy, } 6 \text { Gy and } 8 \text { Gy groups }}<0.05$; $P_{\text {Control vs. } 10 \text { Gy group }}<0.01$; Fig. 3 ). Compared to 2 Gy group ( $1.06 \pm 0.14$-fold change), the mRNA level of caspase-3 amplified in 8 Gy (1.57 \pm 0.31 fold change) and 10 Gy groups $\left(2.17 \pm 0.41\right.$-fold change) ( $P_{2}$ Gy group vs. 8 Gy group $<0.05 ; P_{2}$ Gy group vs. 10 Gy group $<0.01)$. Furthermore, we showedthat $10 \mathrm{~Gy}$ irradiation cased a significant upturn in expression of caspase-3 as compared to $4 \mathrm{~Gy}$ and 6 Gy irradiation ( $P<0.05$; Fig. 3 ). Calculating caspase- 9 /caspase-8 ratio may signify extrinsic/extrinsic apoptosis pathway switch. We found that this ratio was rather than 1fold change in all groups and upon increase in dose of irradiation, a slight increase but not significant was observed ( $P>0.05 ;$ Fig. 3). Data indicated that apoptotic genes increased in a dose-dependent manner.

\section{Electron beam irradiation amplified expression of Sox-2 and Oct-4 genes}

Comparative quantities of transcripts contributing in the stemness and self-renewal of MCF-7 cells were monitored by real-time PCR investigation. Results showed that $10 \mathrm{~Gy}$ irradiation elevated mRNA distribution of Sox-2 in MCF-7 cells ( $P_{\text {control, } 2 \text { Gy, and 4Gy groups vs.10Gygroup }}<0.05$; Fig. 4). Additionally, the transcript level of Oct- 4 increased in high doses of EBI $\left(P_{\text {Control vs. } 6 \text { and } 8 \text { Gy groups }}<0.05\right.$; $P_{\text {Control vs.10 Gy }}$ group $<.01$; Fig. 4). Compared to 2 Gy group, the expression level of Oct-4 increased in $6 \mathrm{~Gy}, 8 \mathrm{~Gy}$, and 10 Gy groups $\left(P_{2}\right.$ Gy vs.6 Gy and 8 Gy groups $<0.05 ; P_{2}$ Gy vs.10 Gy group $\left.<0.01\right)$. There was a significant difference between $4 \mathrm{~Gy}(1.88 \pm 0.62$ fold change) and $10 \mathrm{~Gy}(4.15 \pm 0.41$ fold change) groups $(P<0.05)$ (Fig. 4$)$. Data showed exposure to electron beam, up-regulated expression of stemness genes such as Sox-2 and Oct-4 inMCF-7 cells.

\section{Wound healing rate of MCF-7 cells enhanced following exposure to electron beam}

In vitro scratch assay was established to monitor effect of EBlon wound healing rate and migration potential of MCF-7 cells. Obtained results in this panel revealed that EBI dose-dependentlyenhanced wound healing rate of MCF-7 cells within $48 \mathrm{~h}$ ( $P_{\text {Control vs.6 Gy group }}<0.05$; $P_{\text {Control vs.8 Gy and10 Gy groups }}$ 
0.00001 ; Fig. 5A, B). Compared to 2 Gy group, the wound healing rate significantly elevated in $6 \mathrm{~Gy}, 8 \mathrm{~Gy}$, and 10 Gy groups ( $P_{2}$ Gy vs.6 Gy group $<0.05 ; P_{2}$ Gy vs 8 Gy and10 Gy groups $\left.<0.0001\right)$. The same results obtained as either 4 Gy group or 6 Gy group compared with both $8 \mathrm{~Gy}$ and $10 \mathrm{~Gy}$ groups $\left(P_{4}\right.$ Gy group vs.8Gygroup $<$ $0.001 ; P_{4}$ Gy group vs.10Gygroup $<0.0001 ; P_{6}$ Gy group vs. 8 Gy group $<0.01 ; P_{6}$ Gy group vs. 10 Gy group $<0.001 ;$ Fig. 5A, B).

\section{Condition media from irradiated MCF-7 cells decreased survival rate of MCF-7cells, MSCs, and HUVECs}

The cell survival rate of non-irradiated MCF-7 cells, HUVECs and MSCs co-cultured with CMs of MCF-7 cells investigated using MTT assay. As shown in Fig.6, there is a significant difference between control and control-CM groups $(P<0.05)$. In addition, irradiated CMs decreased survival rate of MCF-7 cells ( $P_{\text {Control and control-CM vs.2, 4, 6, 8, and10 Gy-CM groups }}$ 0.00001; Fig. 6A). Incubation of HUVECs with CMs from MCF-7 cells represented a substantial reduction in cell viability as compared to control group ( $P_{\text {Control vs. }}$ control-CM, 2, 4, 6, 8, and 10 Gy-CM groups $<0.00001$; Fig. 6B). Compared with the Control-CM group, cell viability rate declined in 8 Gy-CM and 10 Gy-CM groups.

In the case of MSCs, irradiated CMs also profoundly decreased the viability of MSCs ( $P_{\text {Control vs. control-CM, }}$ $2,4,6,8$, and 10 Gy-CM groups $<0.00001$; Fig. 6C). Furthermore, the comparison of the viability of MCF-7 cells, HUVECs, and MSCs are presented in Fig. 6D.

\section{Irradiated conditioned media from MCF-7 cells increased apoptosis rate of MCF-7 cells}

We also monitored the apoptosis rate of MCF-7 cells following incubation with CMs from irradiated MCF7 cells. Flow cytometric analysis showed that $\mathrm{CMs}$ increased the percentage of apoptotic cells in a dosedependent manner $\left(P_{\text {control vs. control-cm group }}<0.05 ; P_{\text {control vs. } 2 \text { Gy-CM group }}<0.001 ; P_{\text {control vs. } 4,6 \text {, and } 10 \text { Gy-CM }}\right.$ groups $<0.0001$; Fig 6E, F).

Compared to the Control-CM, a significant increase in apoptosis rate of cells incubated with irradiated CMs was found ( $\left.\mathrm{P}_{\mathrm{CM}-\text { control vs. } 2 \text { and } 4 \mathrm{~Gy} \text {-cm groups }}<0.05 ; P_{\mathrm{CM} \text {-control vs. 6, 8, and } 10 \mathrm{~Gy}-\mathrm{cm} \text { groups }}<0.01\right)$.

\section{Irradiated CMs from MCF-7 cells induced expression of caspase-9, caspase-8, and caspase- 3 genes in MCF-7 cells}

As shown in Fig. 7, the mRNA level of casspase-9 dose-dependently amplified in 8 Gy-CM and 10 Gy-CM groups when compared with both control and control-CM groups $\left(P_{\text {control vs. } 6 \text { Gy-cm group }}<0.05\right.$; $P_{\text {control and }}$

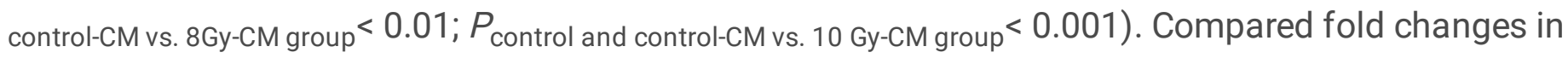
caspase- 9 of both $2 \mathrm{~Gy}-\mathrm{CM}(1.28 \pm 0.15$-fold change) and $4 \mathrm{~Gy}-\mathrm{CM}(1.45 \pm 0.09$-fold change) groups, these values reached $1.80 \pm 0.14$ and $2.36 \pm 0.32$ fold changes in $8 \mathrm{~Gy}-\mathrm{CM}$ and $10 \mathrm{~Gy}-\mathrm{CM}$ groups respectively $(P<0.01$; Fig. 7). The similar result was achieved when $6 \mathrm{~Gy}-\mathrm{CM}$ group compared with $10 \mathrm{~Gy}-$ CM group $(P<0.01)$. 
Similar to expression pattern of caspase-9, CMs from high dose-irradiated cells had potential to induce profoundly the expression of caspase-8 ( $P_{\text {control vs. } 8 \text { Gy-cm group }}<0.05$; $P_{\text {control vs. } 10 \text { Gy-CM group }}<0.01 ; P_{\text {control- }}$ $\mathrm{CM}$ and $2 \mathrm{~Gy}-\mathrm{CM}$ groups vs. 10 Gy-CM group $<0.01$; Fig. 7). In comparison with $4 \mathrm{~Gy}-\mathrm{CM}$ and $6 \mathrm{~Gy}-\mathrm{CM}$ groups, the mRNA level of caspase-8 was significantly elevated in $10 \mathrm{~Gy}$-CM group (1.40 \pm 1.00 and $1.43 \pm 0.13$ vs. $2.12 \pm 0.31$-foldchange; $P<0.01$ ).

We also found that $\mathrm{CMs}$ from electron beam irradiated cells induced significantly expression of caspase3 in MCF-7 cells in a dose-dependent manner $\left(P_{\text {control vs. } 4 \text { Gy-CM and } 6 \text { Gy-cm group }}<0.05\right.$; $P_{\text {control vs. } 8 \text { Gy-CM }}$

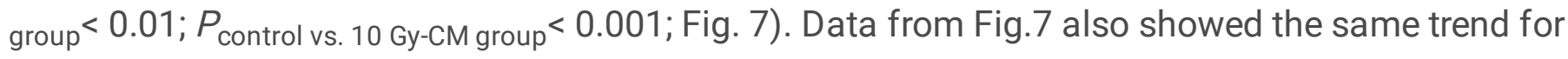
control-CM group as compared with other groups ( $P_{\text {control-CM vs. } 6 \text { Gy-CM }}<0.05$; $P_{\text {control-CM vs. } 8 \text { Gy-CM group }}<$

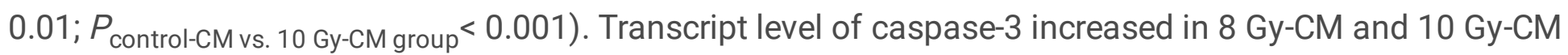
groups when compared either with $2 \mathrm{~Gy}-\mathrm{CM}$ group or $4 \mathrm{~Gy}$-CM group $(P<0.01)$. Furthermore, the mRNA form of caspase-3 significantly increased in 8 Gy-CM group and $10 \mathrm{~Gy}-\mathrm{CM}$ group as compared with $6 \mathrm{~Gy}$ CM group ( $P_{6}$ Gy-CM vs. 8 Gy-cm group $<0.05 ; P_{6}$ Gy-CM group vs. 10 Gy-CM group $<0.01 ;$ Fig.7).

\section{Irradiated CMs from MCF-7 cells induced expression of Sox-2 and Oct-4 genes in MCF-7 cells}

Gene expression assessment by real time-PCR showed that CMs from $8 \mathrm{~Gy}$ and $10 \mathrm{~Gy}$ irradiated MCF-7

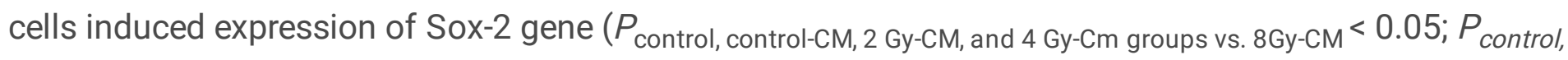
control-CM, 2 Gy-CM, and 4 Gy-Cm groups vs. 10Gy-CM $<0.01$; Fig. 8). The mRNA level of Sox-2 increased in 8 Gy-CM and $10 \mathrm{~Gy}$-CM groups as compared to $6 \mathrm{~Gy}$-CM group $(P<0.05)$. Similar to Sox-2 gene, we also found that the other self-renewal gene, Oct-4, up-regulated in $8 \mathrm{~Gy}-\mathrm{CM}$ and $10 \mathrm{~Gy}-\mathrm{CM}$ groups as compared with other

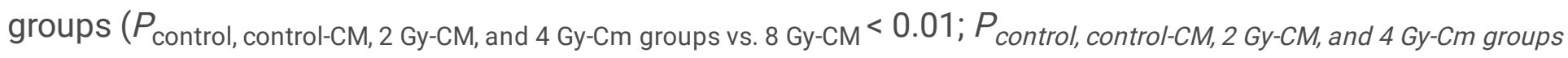
vs. $10 \mathrm{~Gy}-\mathrm{CM}<0.001$; Fig. 8). Additionally, in comparison with $6 \mathrm{~Gy}$-CM group ( $1.38 \pm 0.26$-fold change), the mRNA levels of Oct- 4 were increased in $8 \mathrm{~Gy}-\mathrm{CM}(2.48 \pm 0.16)$ and $10 \mathrm{~Gy}-\mathrm{CM}(3.35 \pm 0.29$-fold change) groups $(P<0.05$ and $P<0.01$; respectively). Analysis of caspase- $9 /$ caspase- 8 ratio showed that this ratio reached slightly rather than 1 -fold in all groups without any significant differences among groups (P>0.05; Fig. 8).

\section{Conditioned media from MCF-7 cells increased wound healing rate of MCF-7 cells}

To investigate the effect of irradiated CMs on wound healing rate and migration of MCF-7 cells, we established in vitro scratch assay. Our results showed that $8 \mathrm{~Gy}$ and $10 \mathrm{~Gy}$ irradiated $\mathrm{CMs}$ a long with control raised the wound healing rate of MCF-7 cells over $48 \mathrm{~h}$ incubation $\left(P_{\text {control-CM, } 2 \text { Gy-CM, } 4 \text { Gy-CM, } 6 \text { Gy-CM }}\right.$ groups vs. 8 Gy-CM, 10 Gy-CM, and control groups $<0.00001$; Fig. 9A,B). In addition, the wound healing rate increased in $10 \mathrm{~Gy}-\mathrm{CM}$ and control groups as compared to $8 \mathrm{~Gy}$-CM group $\left(P_{8 G y-C M}\right.$ group vs. control and $10 \mathrm{~Gy}-\mathrm{CM}$ groups $<0.01$ ). Interestingly, we found that the wound healing rate of control group increased; that supposedly due to incubation in fresh DMEM containing FBS.

\section{Discussion}


In the current study, the effect of different doses of EBI on dynamic of the MCF-7 cells was evaluated. Furthermore, we examined the bystander effects of irradiated MCF-7 cells on the different cell lines, which are known play pivotal roles in cancer treatment. Consistent with previous studies $(20,21)$, we found that the cell viability and apoptosis rate of irradiated MCF-7 cells were dose-dependently decreased and increased respectively (Fig. 1). Irradiation elicit cytotoxic effects on the dynamic of cells through damaging to biomolecules and organelles that induces apoptosis $(22,23)$. According to increase in electron beam dose, the ROS production inside cells increased (Fig. 2A), which may correlated to induction of toxicity in cells and elevated apoptosis rate (24). Different caspases contribute to flow apoptosis both in intrinsic and extrinsic pathways (25), which we examined the mRNA levels of caspase$3,-8,-9$ in irradiated MCF-7 cells over a period of $48 \mathrm{~h}$ of post-irradiation. Caspase- 9 and caspase-8, the cysteine proteases, are implicated in intrinsic and extrinsic apoptosis respectively that activate apoptosis through interacting with caspase-3 (25). Our result showed an increase in the transcript levels of all caspase-3, -8, -9 genes (Fig 3). Increased expression levels of these genes were concomitantly seen with higher level of ROS production in MCF-7 cells that correlated with the result of apoptosis assay. We also calculated caspase-9/caspase-8 ratio to predict the relative superiority of intrinsic or extrinsic pathways in our study. This ratio was rather than 1 value in all irradiated groups, however, the significant difference between them was not observed (Fig 3). These data support an idea that the majority of apoptosis may occur through intrinsic pathway in electron beam received cells. Electron beam could harms cellular biomolecules and organelles (23) and produce ROS (26) that may activates apoptosis intrinsic pathway. In addition, we found that the AChE activity of conditioned media of irradiated cells had elevated in a dose-dependent manner (Fig. 2B) suggesting increased secretion of extracellular vesicles from irradiated cells (27). A recent study by Arscott et al. has confirmed that IR induced extracellular vesicles biogenesis and secretion (28), which may explain the mechanism that intracellular cytotoxicity is expelled by these vesicles for maintain homeostasis and adaptation (29). Based on our knowledge this is first report of increased AChE activity of CMs of MCF-7 cells following exposure to electron beam. It seems that EBI influenced ROS/apoptosis/EVs secretion axis in MCF-7 cells. Beside these, we measured the effect of EBI on MCF-7 cells regarding stemness related genes. In this regard, data showed that the expression of Sox2 and Oct-4 increased in irradiated cells (Fig. 4), supposing induction of a stem cell-like phenotype in MCF-7 cells $(30,31)$.This was in accordance with a work by Ghisolfi et alwhich found that gamma irradiation of cancer cells increased mRNA level of Sox-2 and Oct3/4 genes (32). Similarly, it was demonstrated that IR induce the cancer stem like cells via dedifferentiation, and increasing the expression of stem cell markers such as SOX-2 in glioblastoma cells (33). Confirmed that, up-regulation of Sox2 and Oct-4 genes may have a pivotal role in the supporting of self-renewal, reprogramming, and plasticity capacity in cancer stem cells $(34,35)$. Our findings would seem to show the mRNA level of these genes following EBI may represent alternation in the MCF-7 cells population and enrichment of cancer stem cells (36).Concurs well with Imaizumi and colleagues (37), we also found that EBI was capable of inducing migration response of MCF-7 cells by scratch wound healing assay (Fig. 5). Different authorities have shown that irradiation not only induce apoptosis in tumor cells but also encourage motility and invasion of tumor cells through several pathways $(38,39)$. Further data collection is required to uncover underling mechanisms involved in EBI mediated cell migration. 
Furthermore, we aimed to investigate bystander effect of EBI on non-irradiated cells. In this scenario, we noted that treatment of MCF-7 cells, MSCs, and HUVECs with CMs from irradiated MCF-7 cells decreased viability of all cell lines (Fig. 6A-D). Jella and co-workers (40) proved the decrease in viability of tumor cells which co-cultured with $\mathrm{CMs}$ of irradiated cells. They also revealed a remarkable increase in the caspase activity and apoptosis rate of cells received irradiated $\mathrm{CMs}$, which is similar to our results that CMs from irradiated MCF-7 cells increased apoptosis rate of MCF-7 cells. As shown in figure 6A-D, compared to control group, decreased cell viability value of control-CM group may due to presence of FBS in cell culture media of control groups. More recently, Lepleux et al reported that CMs from chondrosarcoma cells irradiated with X-rays and C-ions at different doses ( 0.05 to $8 \mathrm{~Gy})$ suppressed proliferation of T/C-28a2 chondrocytes and decreased cell survival (41). Consistently, Yang et al. found that the percentage of apoptotic A549 cells was increased when cultivated with CMs of irradiated cells, indicating decrease in cell viability (42). For further insight into apoptosis, we monitored expression of apoptotic genes including caspase-3, -8 , and -9 in the CM-treated MCF-7 cells (Fig. 7). Consist with; our results confirmed the up-regulation of those genes in MCF-7 cells cultured with CMs from irradiated MCF7 cells. Increased expression levels of these genes were correlated with increased percentage of Annexin $\checkmark$ positive cells (Fig. $6 \mathrm{E}$ and F). It seems that both intrinsic and extrinsic pathways were activated in our experiment; however, the caspas-9/caspas-8 ratio was rather than 1 in all CM-groups (Fig. 7), indicating more activation of intrinsic pathway. To our knowledge, little is known about the impact of bystander effects of electron beam on cancer stem cell related genes. Interestingly, we found that CMs from irradiated cells induced expression of stemness and self-renewal related genes; Sox-2 and Oct- 4 in MCF-7 cells (Fig. 8). According to previous studies, these genes are involved in resistance and adaption to stress condition $(43,44)$. Bystander effects may mediate through different soluble factors, cytokines $(10)$, and even EVs (12). It was well established that bystander effects of IR are consist of chromosomal inconsistence, DNA damage, alteration, resistance, proliferation, and apoptosis in non-irradiated cells (45). Xu and co-workers have reported that X-ray irradiation increase exosomes biogenesis and secretion (46). In addition, several laboratories demonstrated that EVs from irradiated tumor cells promoted genomic instability and resistance in non-irradiated cell $(47,48)$. In our experiment, in part, increased EVs in CMs may explain the up-regulation of these genes in MCF-7 cells. An explanation may be that soluble factors enriched in the CMs of irradiated MCF-7 cells could induce resistance and self-renewal property of MCF-7 cells via up-regulation of Sox-2 and Oct-4 genes. In an attempt to highlight the possible effect of CMs on migration capacity of non-irradiated MCF-7 cells, the increased wound healing rate of MCF-7 cells which treated by CMs from high dose irradiated cells was shown by in vitro scratch assay. These values show a relationship fairly well with Mutschelknaus et al. that further support the idea that cytokines and EVs content of irradiated CMs contribute to promote migration ability of MCF-7 cells (49). As presented in figure $9, \mathrm{CMs}$ from high doses (8 Gy and $10 \mathrm{~Gy}$ ) irradiated cells induced significantly migration which presumably due to increased such cytokines in high dose irradiated cells. Moreover, we found that the wound healing rate of control cells increased, which may be owing to culture in freshly medium containing FBS that promotes cell proliferation. The results point to the probability that population of MCF-7 cells under electron beam exposure release soluble factors including EVs not only for expel cellular damage but also for induce resistance and compensatory responses against stress condition.

Page $11 / 27$ 
In summary, through investigating irradiated MCF-7 cells with the different doses of electron beam affecting the viability, apoptosis, EVs release, expression of genes involved in apoptosis and stemness, and migration capacity, we shed light into cellular responses of MCF-7 against EBI (Fig. 10). We showed that along with increase in doses of irradiation, the cellular responses increased. Although EBI showed cytotoxic effects, but facilitated EVs secretion, cell migration, and up-regulation of Sox2 and Oct-4 in MCF-7 cells, which may represent side effects of EBI. Additionally, by studying possibly bystander effects of EBI, we uncovered that irradiated MCF-7 cells sent signals through paracrine manner that influence survival and apoptosis rate of non-irradiated cells (Fig. 10). These signals from high dose irradiated cells also induced stemness and resistance in tumor cell population; and even promoted wound healing rate indicating elevated migration potential of MCF-7 cells.

\section{Conclusion}

Although the current study analyzed in vitro response of MCF-7 cells against EBI, our results showed thatMCF-7 cells treated with electron beam and CMs from irradiated MCF-7 cells exhibit an up-regulation in both genes involved in apoptosis pathway and stemness. Therefore, further studies are essential to elucidate the exact underlying mechanisms involved in EBI induced alternation in dynamic of tumor cells.

\section{Abbreviations}

AChE: Acetylcholinesterase

CM: Conditioned media

DCFH-DA: Dichlorofluorescein diacetate

DMEM: Dulbecco's Modified Eagle Medium

DMSO: Dimethyl sulfoxide

EBI: Electron beam irradiation

EVs: Extracellular vesicles

FBS: Fetal bovine serum

HUVECs: Human umbilical vein stem cells

IOERT: Intraoperative electron radiotherapy

IORT: Intraoperative radiation therapy

IR: lonizing radiation 
MSCs: Mesenchymal stem cells

MU: Monitor unit

NTEs: Non-targeting effects

OD: Optical density

PBS: Phosphate-buffered saline

ROS: Reactive oxygen species

\section{Declarations}

\section{Ethical approval}

The ethics committee of Urmia University of Medical Sciences approved the all procedures of this experiment (ethical approval no: IR.UMSU.REC.1398.101).

\section{Consent for publication}

All authors have given consent for publication.

\section{Declaration}

The authors declare that they have no conflicts of interest.

\section{Availability of supporting data}

Not applicable

\section{Funding}

The current work was supported by a grant number: IR.UMSU.REC.1398.101

\section{Authors' contributions}

$\mathrm{NJ}$ and JR were responsible for the conceptualization and acquisition of the data. NJ and JR were responsible for the methodology. NJ and JR were responsible for the writing, review, and/or revision of the manuscript. MF, NJ, JR and KM were responsible for the administrative, technical, or material support. $\mathrm{NJ}$ was responsible for the study supervision. All authors read and approved the final manuscript.

\section{Acknowledgements}

Not applicable 


\section{Authors' information}

MF is a Master of advanced studies in Medical Physics, Urmia University of Medical Sciences, Urmia, Iran. NJ and JR are faculty membranes of Urmia University of Medical Sciences, Urmia, Iran. KM is a radiotherapy technician at Omid Research and Treatment Center, Urmia, Iran.

\section{References}

1. Bray F, Ferlay J, Soerjomataram I, Siegel RL, Torre LA, Jemal A. Global cancer statistics 2018 : GLOBOCAN estimates of incidence and mortality worldwide for 36 cancers in 185 countries. CA: a cancer journal for clinicians. 2018;68(6):394-424.

2. Garrido-Castro AC, Lin NU, Polyak K. Insights into molecular classifications of triple-negative breast cancer: improving patient selection for treatment. Cancer discovery. 2019;9(2):176-98.

3. Jabbari N, Zarei L, Esmaeili Govarchin Galeh H, Mansori Motlagh B. Assessment of synergistic effect of combining hyperthermia with irradiation and calcium carbonate nanoparticles on proliferation of human breast adenocarcinoma cell line (MCF-7 cells). Artificial cells, nanomedicine, and biotechnology. 2018:1-9.

4. Tutt A, Yarnold J. Radiobiology of breast cancer. Clinical oncology. 2006;18(3):166-78.

5. Kadhim M, Salomaa S, Wright E, Hildebrandt G, Belyakov OV, Prise KM, et al. Non-targeted effects of ionising radiation-implications for low dose risk. Mutation Research/Reviews in Mutation Research. 2013;752(2):84-98.

6. Sedlmayer F, Fastner G, Merz F, Deutschmann H, Reitsamer R, Menzel C, et al. IORT with electrons as boost strategy during breast conserving therapy in limited stage breast cancer: results of an ISIORT pooled analysis. Strahlentherapie und Onkologie. 2007;183:32-4.

7. Piotrowski I, Kulcenty K, Wichtowski M, Murawa D, Suchorska W. Intraoperative radiotherapy of breast cancer and its biological effects. Breast care. 2017;12(2):107-11.

8. Babayan N, Hovhannisyan G, Grigoryan B, Grigoryan R, Sarkisyan N, Tsakanova G, et al. Dose-rate effect of ultrashort electron beam radiation on DNA damage and repair in vitro. Journal of radiation research. 2017;58(6):894-7.

9. Chien L, Chen W-K, Liu S-T, Chang C-R, Kao M-C, Chen K-W, et al. Low-dose ionizing radiation induces mitochondrial fusion and increases expression of mitochondrial complexes I and III in hippocampal neurons. Oncotarget. 2015;6(31):30628.

10. Marín A, Martín M, Liñán $O$, Alvarenga F, López $M$, Fernández $L$, et al. Bystander effects and radiotherapy. Reports of Practical Oncology \& Radiotherapy. 2015;20(1):12-21.

11. Jabbari N, Karimipour M, Khaksar M, Akbariazar E, Heidarzadeh M, Mojarad B, et al. Tumor-derived extracellular vesicles: insights into bystander effects of exosomes after irradiation. Lasers in medical science. 2019:1-15.

12. Nawaz M, Fatima F. Extracellular vesicles, tunneling nanotubes, and cellular interplay: synergies and missing links. Frontiers in molecular biosciences. 2017;4:50. 
13. Najafi M, Fardid R, Hadadi G, Fardid M. The mechanisms of radiation-induced bystander effect. Journal of biomedical physics \& engineering. 2014;4(4):163.

14. Zhang D, Zhou T, He F, Rong Y, Lee SH, Wu S, et al. Reactive oxygen species formation and bystander effects in gradient irradiation on human breast cancer cells. Oncotarget. 2016;7(27):41622.

15. Diamond JM, Vanpouille-Box C, Spada S, Rudqvist N-P, Chapman J, Ueberheide B, et al. Exosomes shuttle TREX1-sensitive IFN-stimulatory dsDNA from irradiated cancer cells to dendritic cells. Cancer immunology research. 2018:canimm. 0581.2017.

16. Abramowicz A, Wojakowska A, Marczak L, Lysek-Gladysinska M, Smolarz M, Story MD, et al. lonizing radiation affects the composition of the proteome of extracellular vesicles released by head-andneck cancer cells in vitro. Journal of radiation research. 2019;60(3):289-97.

17. Folkard M, Prise K, Michette A, Vojnovic B. The use of radiation microbeams to investigate the bystander effect in cells and tissues. Nuclear Instruments and Methods in Physics Research Section A: Accelerators, Spectrometers, Detectors and Associated Equipment. 2007;580(1):446-50.

18. Piotrowski I, Kulcenty K, Wichtowski M, Murawa D, Suchorska W. Intraoperative Radiotherapy of Breast Cancer and Its Biological Effects. Breast care (Basel, Switzerland). 2017;12(2):109-13.

19. Maluta S, Dall'Oglio S, Goer DA, Marciai N. Intraoperative electron radiotherapy (IOERT) as an alternative to standard whole breast irradiation: only for low-risk subgroups? Breast care. 2014;9(2):102-

20. Lee KB, Lee J-S, Park J-W, Huh T-L, Lee YM. Low energy proton beam induces tumor cell apoptosis through reactive oxygen species and activation of caspases. Experimental \& molecular medicine. 2008;40(1):118.

21. Mehrnia SS, Hashemi B, Mowla SJ, Arbabi A. Enhancing the effect of $4 \mathrm{MeV}$ electron beam using gold nanoparticles in breast cancer cells. Physica Medica. 2017;35:18-24.

22. Sanche L. Low energy electron-driven damage in biomolecules. The European Physical Journal DAtomic, Molecular, Optical and Plasma Physics. 2005;35(2):367-90.

23. Alizadeh E, Orlando TM, Sanche L. Biomolecular damage induced by ionizing radiation: the direct and indirect effects of low-energy electrons on DNA. Annual review of physical chemistry. 2015;66:379-98.

24. Azzam El, Jay-Gerin J-P, Pain D. lonizing radiation-induced metabolic oxidative stress and prolonged cell injury. Cancer letters. 2012;327(1-2):48-60.

25. Elmore S. Apoptosis: a review of programmed cell death. Toxicologic pathology. 2007;35(4):495-516.

26. Ma S, Ke Z, Huang Q. Study of the high-energy electron-beam irradiation induced damage on the model protein horseradish peroxidase. Nuclear Physics Review. 2016;33(1):88-93.

27. Martins TS, Catita J, Rosa IM, e Silva OAdC, Henriques AG. Exosome isolation from distinct biofluids using precipitation and column-based approaches. PloS one. 2018;13(6):e0198820.

28. Arscott WT, Tandle AT, Zhao S, Shabason JE, Gordon IK, Schlaff CD, et al. Ionizing radiation and glioblastoma exosomes: implications in tumor biology and cell migration. Translational oncology. 
2013;6(6):638-IN6.

29. Jelonek K, Wojakowska A, Marczak L, Muer A, Tinhofer-Keilholz I, Lysek-Gladysinska M, et al. lonizing radiation affects protein composition of exosomes secreted in vitro from head and neck squamous cell carcinoma. Acta Biochimica Polonica. 2015;62(2).

30. Bissell MJ, LaBarge MA. Context, tissue plasticity, and cancer: are tumor stem cells also regulated by the microenvironment? Cancer cell. 2005;7(1):17-23.

31. Hendrix MJ, Seftor EA, Seftor RE, Kasemeier-Kulesa J, Kulesa PM, Postovit L-M. Reprogramming metastatic tumour cells with embryonic microenvironments. Nature Reviews Cancer. 2007;7(4):246.

32. Ghisolfi L, Keates AC, Hu X, Lee D-k, Li CJ. lonizing radiation induces stemness in cancer cells. PloS one. 2012;7(8):e43628.

33. Dahan P, Gala JM, Delmas C, Monferran S, Malric L, Zentkowski D, et al. lonizing radiations sustain glioblastoma cell dedifferentiation to a stem-like phenotype through survivin: possible involvement in radioresistance. Cell death \& disease. 2014;5(11):e1543.

34. Atlasi Y, Mowla SJ, Ziaee SA, Bahrami AR. OCT-4, an embryonic stem cell marker, is highly expressed in bladder cancer. International Journal of Cancer. 2007;120(7):1598-602.

35. Gangemi RMR, Griffero F, Marubbi D, Perera M, Capra MC, Malatesta P, et al. SOX2 silencing in glioblastoma tumor-initiating cells causes stop of proliferation and loss of tumorigenicity. Stem cells. 2009;27(1):40-8.

36. Lagadec C, Vlashi E, Della Donna L, Dekmezian C, Pajonk F. Radiation-induced reprogramming of breast cancer cells. Stem cells. 2012;30(5):833-44.

37. Imaizumi H, Sato K, Nishihara A, Minami K, Koizumi M, Matsuura N, et al. X-ray-enhanced cancer cell migration requires the linker of nucleoskeleton and cytoskeleton complex. Cancer science. 2018;109(4):1158-65.

38. Cheng JC, Chou C-H, Kuo M, Hsieh C. Radiation-enhanced hepatocellular carcinoma cell invasion with MMP-9 expression through PI3K/Akt/NF-KB signal transduction pathway. Oncogene. 2006;25(53):7009.

39. Jung J-W, Hwang S-Y, Hwang J-S, Oh E-S, Park S, Han I-O. lonising radiation induces changes associated with epithelial-mesenchymal transdifferentiation and increased cell motility of A549 lung epithelial cells. European journal of cancer. 2007;43(7):1214-24.

40. Jella KK, Moriarty R, McClean B, Byrne HJ, Lyng FM. Reactive oxygen species and nitric oxide signaling in bystander cells. PloS one. 2018;13(4):e0195371.

41. Lepleux C, Marie-Brasset A, Temelie M, Boulanger M, Brotin É, Goldring MB, et al. Bystander effectors of chondrosarcoma cells irradiated at different LET impair proliferation of chondrocytes. Journal of cell communication and signaling. 2019:1-14.

42. Yang S, Xu J, Shao W, Geng C, Li J, Guo F, et al. Radiation-induced bystander effects in A549 cells exposed to 6 MV X-rays. Cell biochemistry and biophysics. 2015;72(3):877-82. 
43. Hadjimichael C, Chanoumidou K, Papadopoulou N, Arampatzi P, Papamatheakis J, Kretsovali A. Common stemness regulators of embryonic and cancer stem cells. World journal of stem cells. 2015;7(9):1150.

44. Shen L, Huang X, Xie X, Su J, Yuan J, Chen X. High expression of SOX2 and OCT4 indicates radiation resistance and an independent negative prognosis in cervical squamous cell carcinoma. Journal of Histochemistry \& Cytochemistry. 2014;62(7):499-509.

45. Pol E, Coumans F, Grootemaat A, Gardiner C, Sargent I, Harrison P, et al. Particle size distribution of exosomes and microvesicles determined by transmission electron microscopy, flow cytometry, nanoparticle tracking analysis, and resistive pulse sensing. Journal of Thrombosis and Haemostasis. 2014;12(7):1182-92.

46. Xu S, Wang J, Ding N, Hu W, Zhang X, Wang B, et al. Exosome-mediated microRNA transfer plays a role in radiation-induced bystander effect. RNA biology. 2015;12(12):1355-63.

47. Jelonek K, Widlak P, Pietrowska M. The influence of ionizing radiation on exosome composition, secretion and intercellular communication. Protein and peptide letters. 2016;23(7):656-63.

48. Ni J, Bucci J, Malouf D, Knox M, Graham P, Li Y. Exosomes in Cancer Radioresistance. Frontiers in oncology. 2019;9:869.

49. Mutschelknaus L, Azimzadeh O, Heider T, Winkler K, Vetter M, Kell R, et al. Radiation alters the cargo of exosomes released from squamous head and neck cancer cells to promote migration of recipient cells. Scientific reports. 2017;7(1):12423.

50. Grosovsky AJ. Radiation-induced mutations in unirradiated DNA. Proceedings of the National Academy of Sciences. 1999;96(10):5346-7.

51. Futaki N, Takahashi S, Yokoyama M, Arai I, Higuchi S, Otomo S. NS-398, a new anti-inflammatory agent, selectively inhibits prostaglandin G/H synthase/cyclooxygenase (COX-2) activity in vitro. Prostaglandins. 1994;47(1):55-9.

52. Yakovlev VA. Role of nitric oxide in the radiation-induced bystander effect. Redox biology. 2015;6:396-400.

53. Verma N, Tiku AB. Significance and nature of bystander responses induced by various agents. Mutation Research/Reviews in Mutation Research. 2017;773:104-21.

54. Willett CG, Del Castillo CF, Shih HA, Goldberg S, Biggs P, Clark JW, et al. Long-term results of intraoperative electron beam irradiation (IOERT) for patients with unresectable pancreatic cancer. Annals of surgery. 2005;241(2):295.

\section{Tables}

Table 1: The list of sequences primers used in the current study 


\begin{tabular}{|l|l|l|}
\hline Genes & \multicolumn{1}{|c|}{ Sequences } & Tm \\
\hline \multirow{2}{*}{ sox2 } & F:AACATGATGGAGACGGAGCTGA & $63^{\circ} \mathrm{C}$ \\
\cline { 2 - 3 } & R: GTCCGGGCTGTTTTTCTGGTTG & \\
\hline \multirow{2}{*}{ Oct4 } & F: CAAGAACATGTGTAAGCTGCGG & $63^{\circ} \mathrm{C}$ \\
\cline { 2 - 3 } & R:TGGTTCGCTTTCTCTTTCGGG & \\
\hline Caspase3 & F: AAACACTAGAAAGGAGGAGATGG & $63^{\circ} \mathrm{C}$ \\
\cline { 2 - 3 } & R:CATGTCATCATCCAGTTTGCATT & \\
\hline Caspase8 & F: AAACACTAGAAAGGAGGAGATGG & $60^{\circ} \mathrm{C}$ \\
\cline { 2 - 3 } & R:CATGTCATCATCCAGTTTGCATT & \\
\hline Caspase9 & F:GACGCCATATCTAGTTTGCCC & $60^{\circ} \mathrm{C}$ \\
\cline { 2 - 3 } & R: CACTGCTCAAAGATGTCGTCC & \\
\hline GAPDH & $\begin{array}{l}\text { F:TTGACCTCAACTACATGGTTTACA } \\
\text { R:GCTCCTGGAAGATGGTGATG }\end{array}$ & \\
\hline
\end{tabular}

\section{Figures}
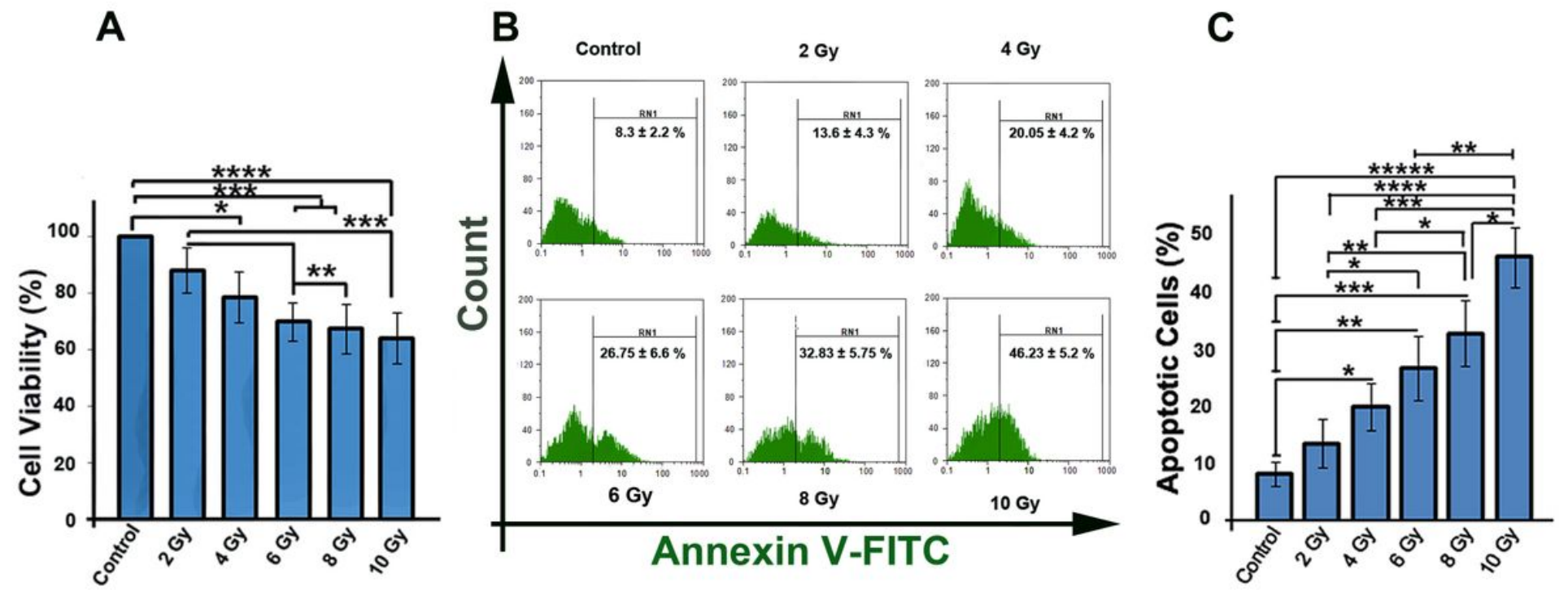

Figure 1

MTT assay and Flow cytometry analysis. Viability of MCF-7 cell decreased after irradiation with beam electron over $48 \mathrm{~h}(\mathrm{~A})$. Flow cytometric data showed a significant increase in percentage of apoptotic cells $(B$ and $C)$. Data are presented as means $\pm S D ; n=3$. One-way ANOVA with Tukey post hoc test. ${ }^{*} P<$

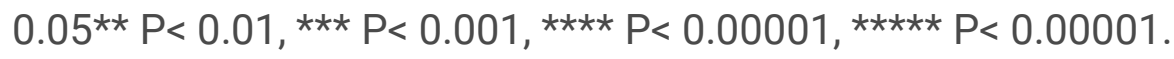



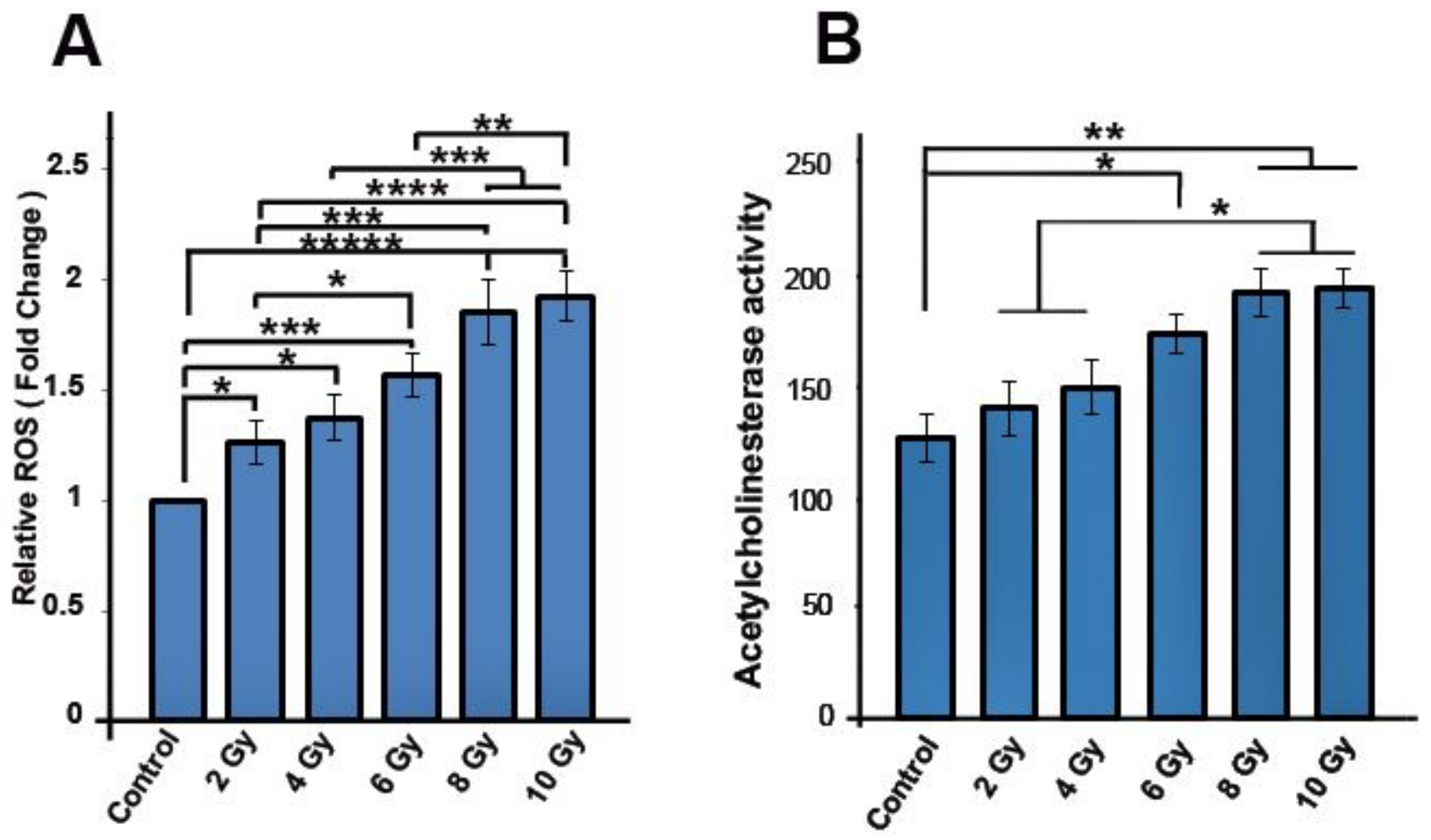

Figure 2

ROS production in MCF-7 cells was determined by chemical fluorometric assay (A). Acetylcholinesterase (AChE) activity in conditioned media of irradiated MCF-cells (B). Data are presented as means $\pm S D ; n=3$.

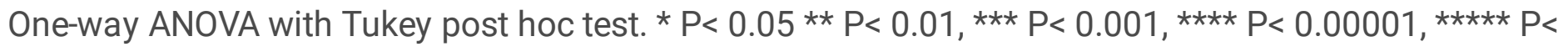
0.00001 . 

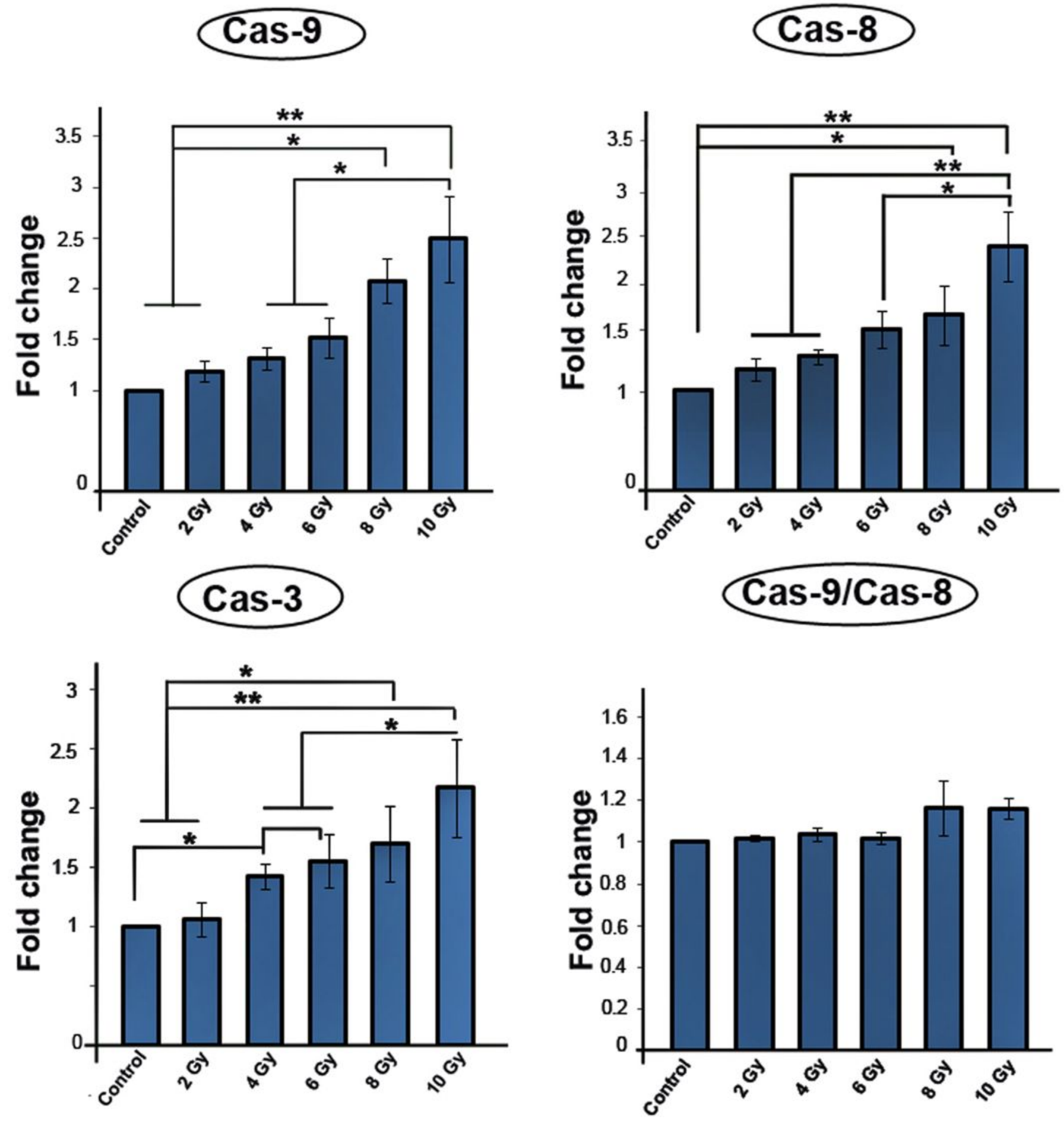

Figure 3

Real time-PCR analysis of caspase-9, caspase-8, and caspase-3 genes involved in apoptosis pathway.Data are presented as means $\pm S D ; n=3$. One-way ANOVA with Tukey post hoc test. * $P<0.05$ ** $P<0.01$. Cas means caspase. 


\section{Sox-2}

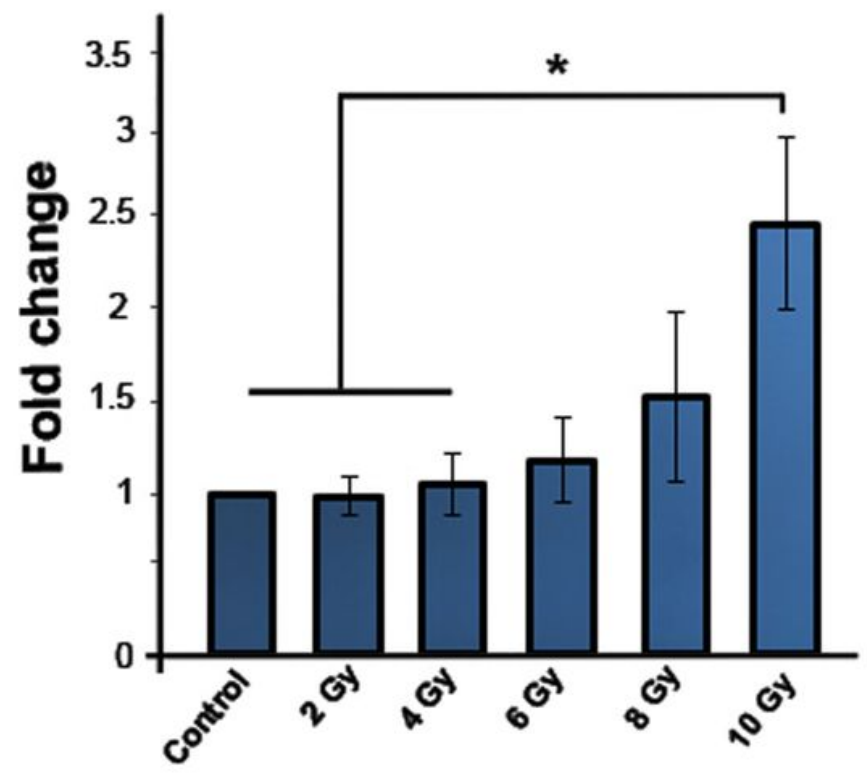

Oct-4

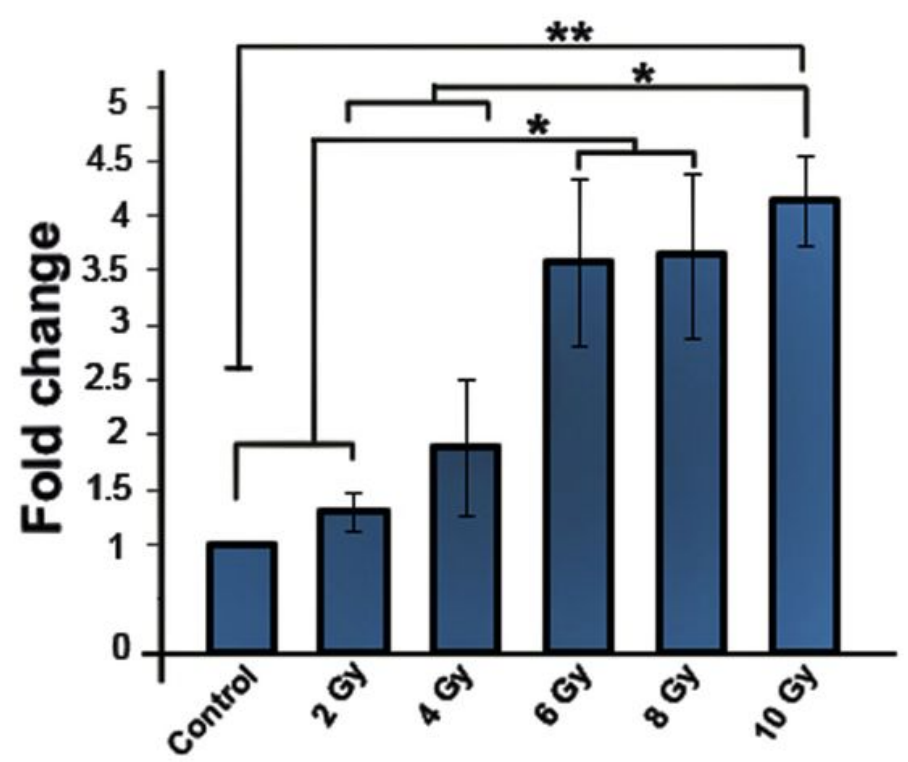

Figure 4

Real time-PCR analysis showed that the transcript level of Sox-2 and Oct-4 increased in MCF-7 cells upon exposure to electron beam irradiation. Data are presented as means $\pm S D ; n=3$. One-way ANOVA with Tukey post hoc test. * $P<0.05$ ** $P<0.01$. 

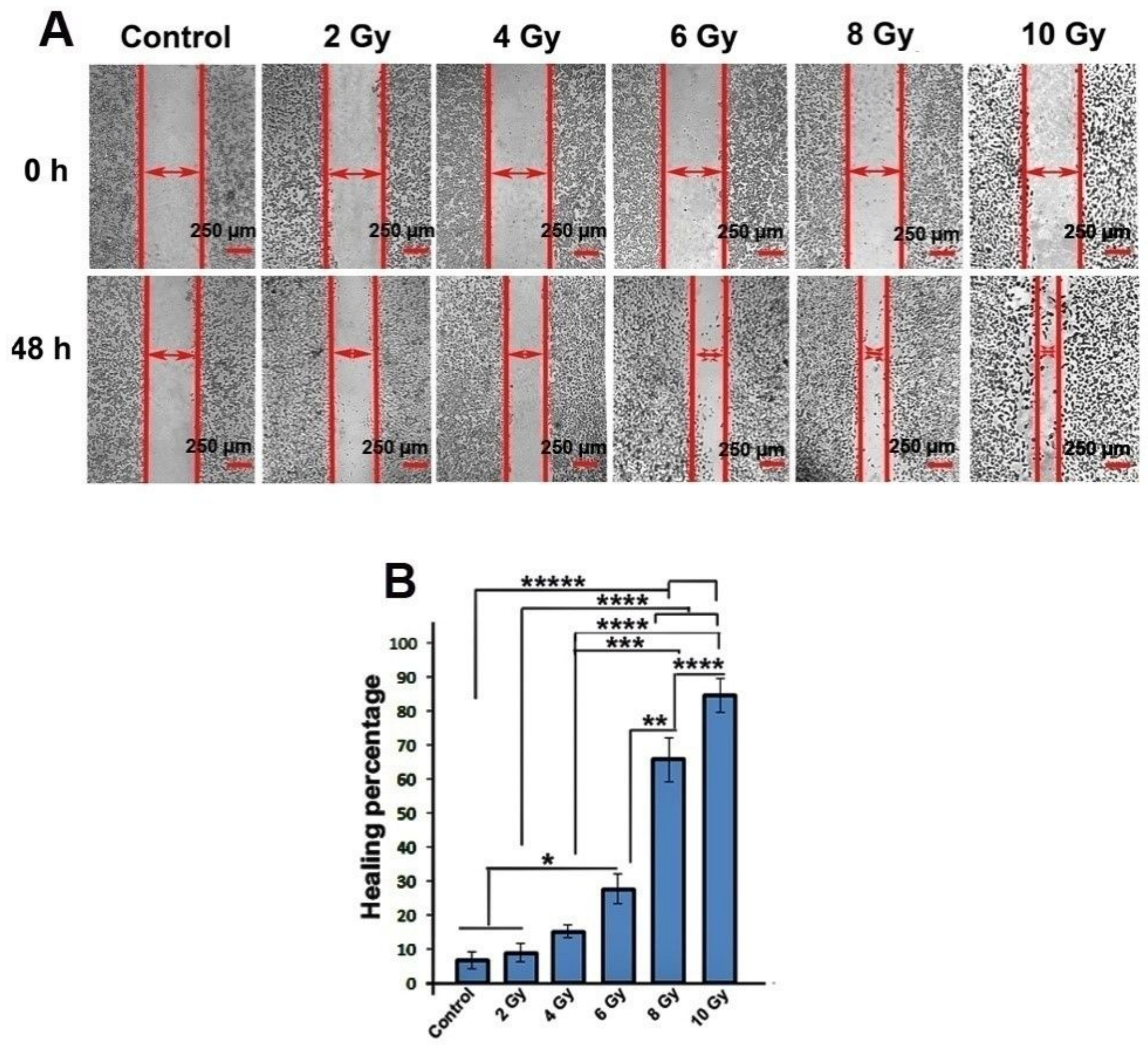

Figure 5

Representative in vitro scratch analysis of wound healing rate of irradiated MCF-7 cells after $48 \mathrm{~h}$ of irradiation ( $A$ and $B$ ).Data are presented as means $\pm S D ; n=3$. One-way ANOVA with Tukey post hoc test.

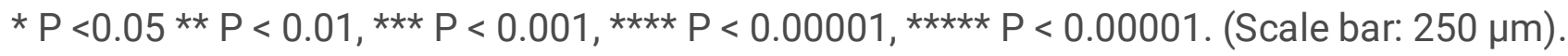




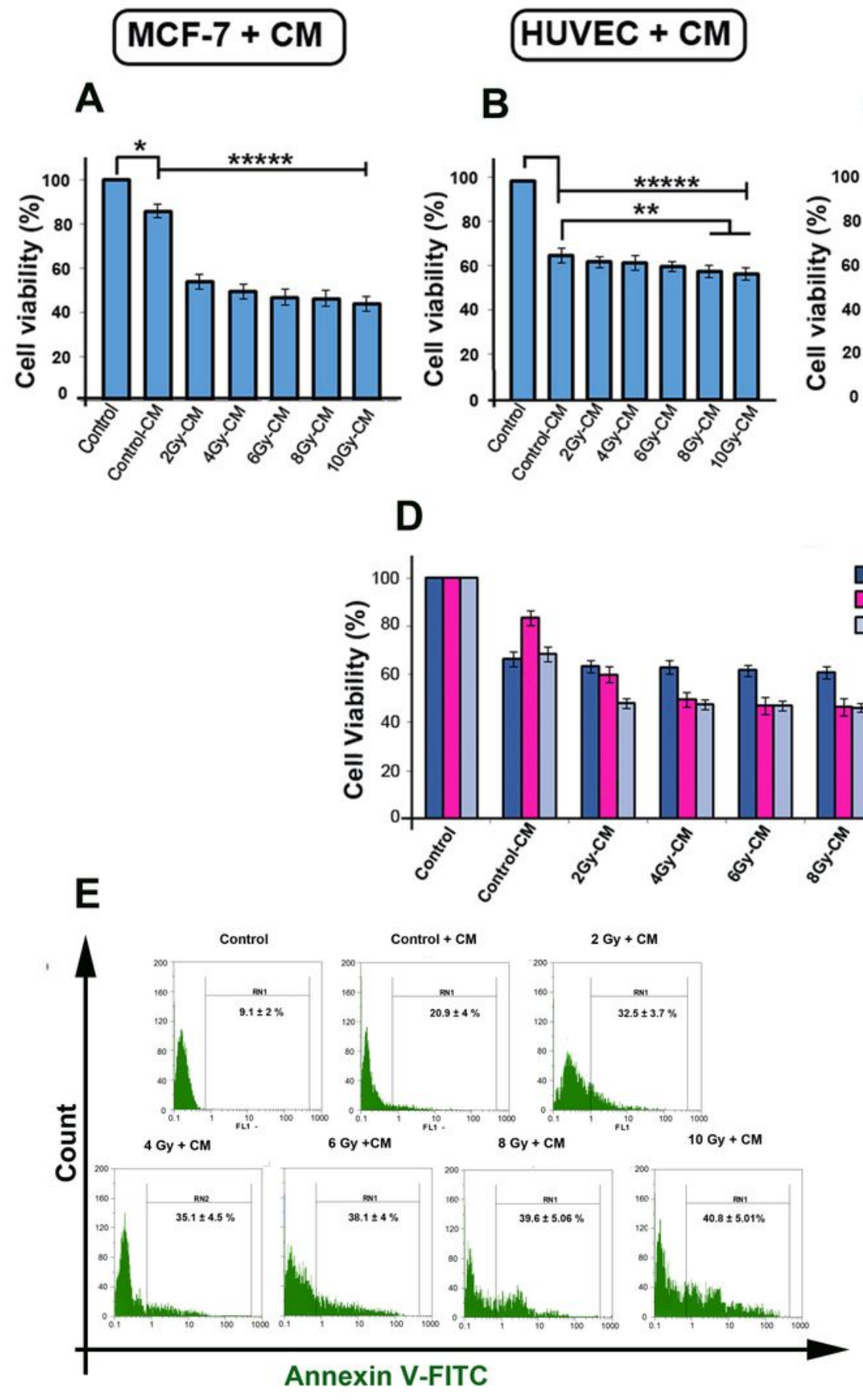

MSC + CM

C

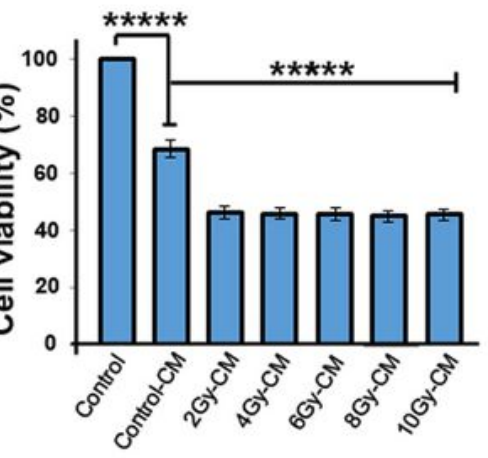

Q HUVEC

口MCF-7
MSC
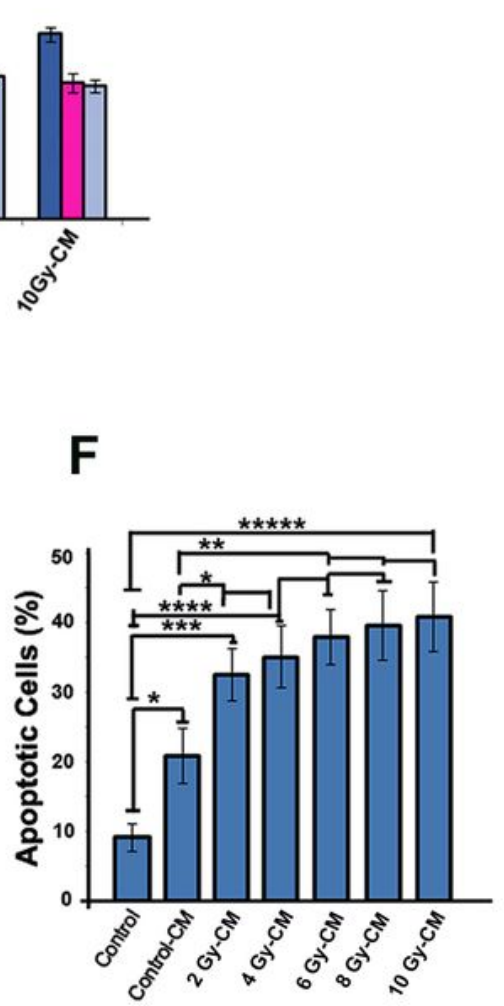

Figure 6

MTT viability showed that conditioned media from irradiated MCF-7 cells decreased viability of MCF-7 cells (A), HUVECs (B), and MSCs (C). Representative comparison of viability of different cell lines used to evaluate effect of conditioned media from MCF-7 cells on (D). Flow cytometry analysis indicted that irradiated MCF-7 cells- derived conditioned media increased apoptosis rate of non-irradiated MCF-7 cells. 
Data are presented as means $\pm S D ; n=3$. One-way ANOVA with Tukey post hoc test. ${ }^{*} P<0.05 * \star P<0.01$, $* \star * \mathrm{P}<0.001, * * * * \mathrm{P}<0.00001, * * * * * \mathrm{P}<0.00001$.
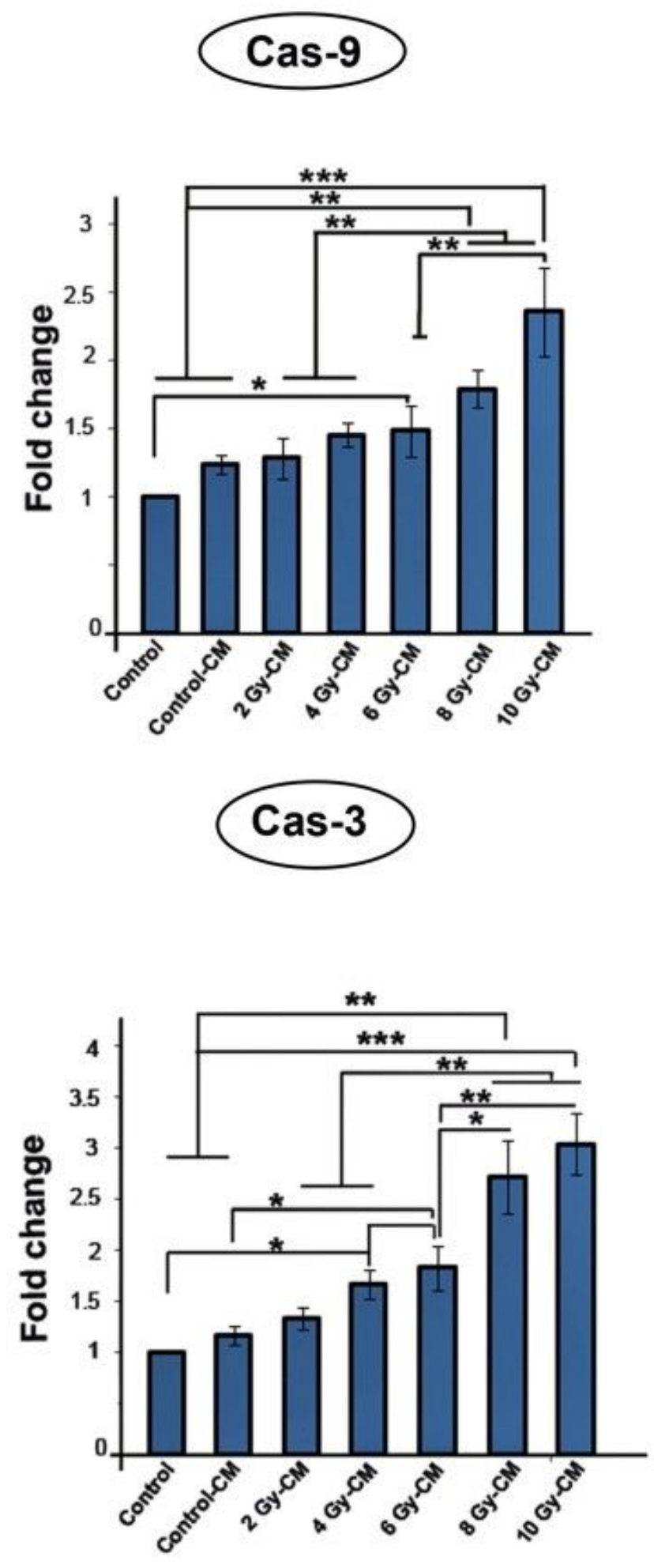
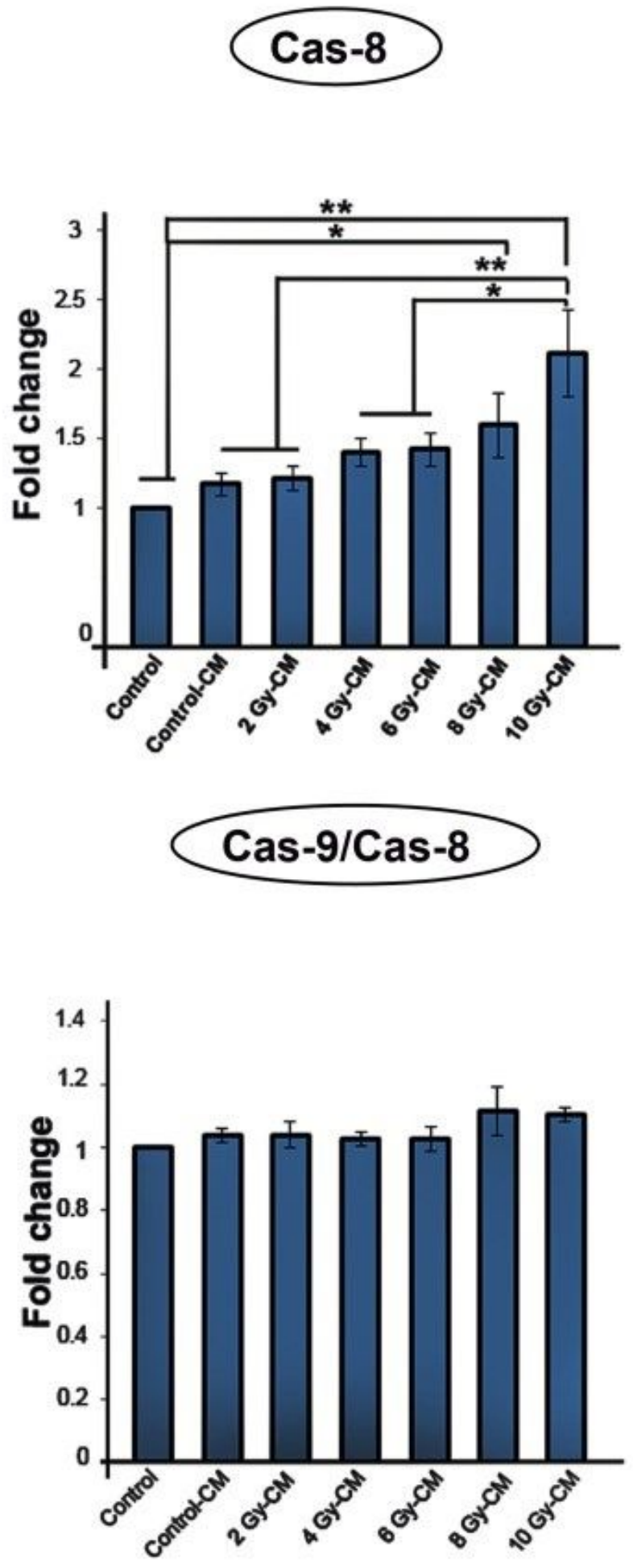

Figure 7

Expression of caspase-9, caspase-8, and caspase-3 genes, involved in apoptosis flux, relatively quantified by real time-PCR in MCF-7 cells.Data are presented as means $\pm S D ; n=3$. One-way ANOVA with Tukey post hoc test. $* \mathrm{P}<0.05 * * \mathrm{P}<0.01$, *** $\mathrm{P}<0.001$. 

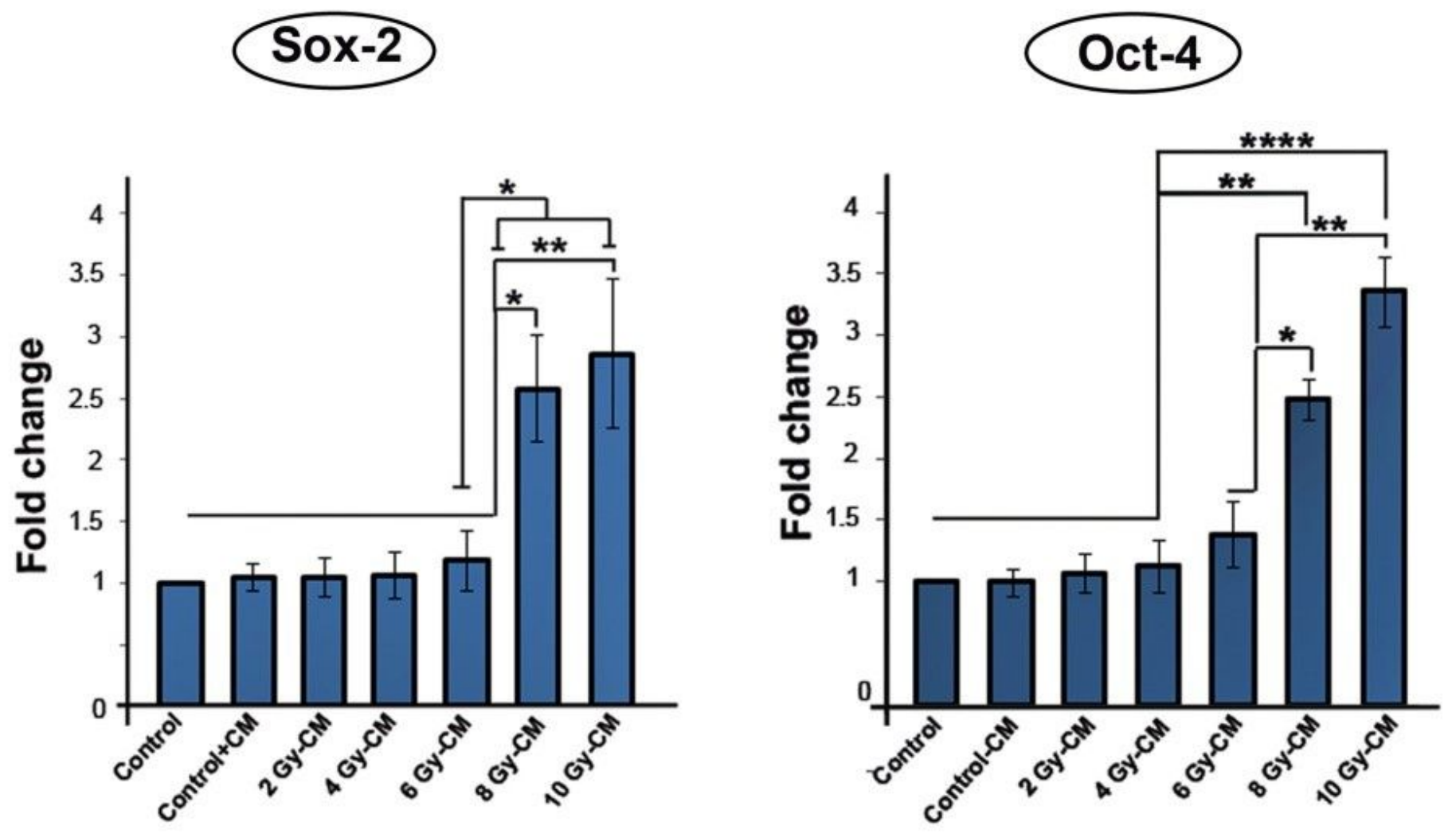

Figure 8

Data obtained from real time-PCR analysis showed that conditioned media ofirradiated MCF-7 cells induced the expression of Sox-2 and Oct-4 genes in MCF-7 cells. Data are presented as means $\pm S D ; n=$ 3. One-way ANOVA with Tukey post hoc test. * $P<0.05 * \star P<0.01$, **** $P<0.0001$. 

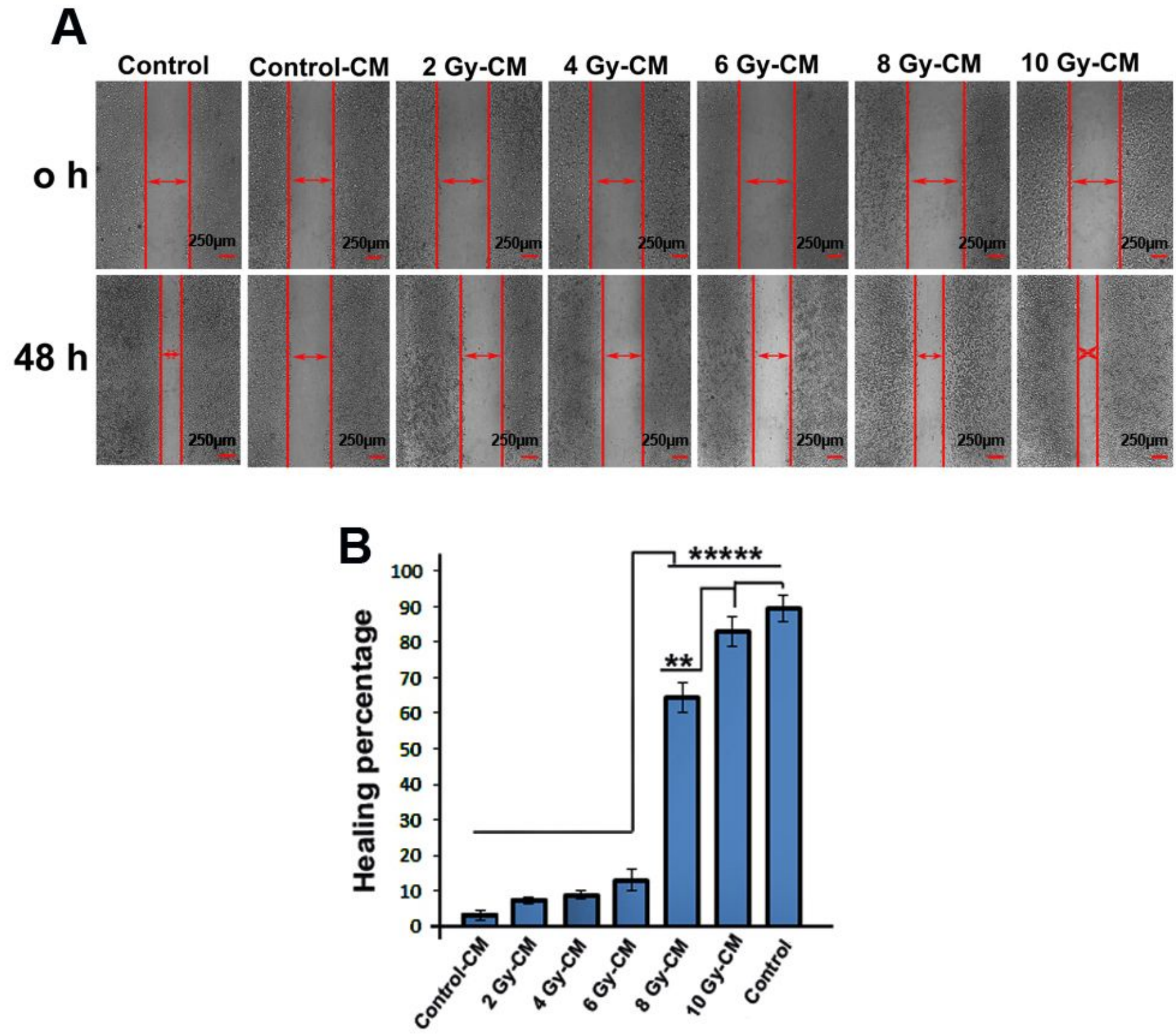

Figure 9

Conditioned media obtained from irradiated MCF-7 cells induced MCF-7 cells migration in a wound healing model $(A$ and $B)$. Data are presented as means $\pm S D ; n=3$. One-way ANOVA with Tukey post hoc test. $* \star P<0.01, \star \star \star \star \star ~ P<0.00001$. 


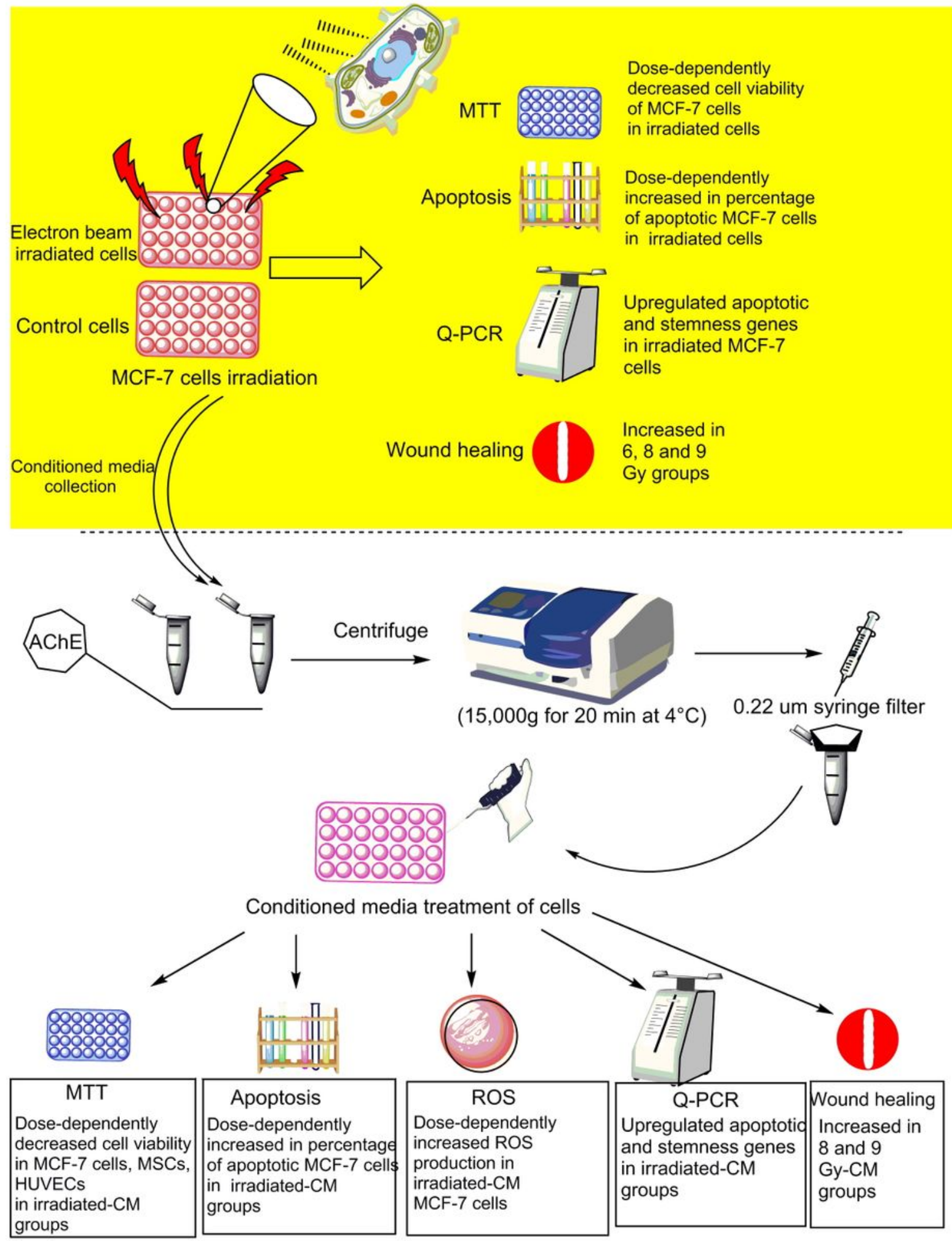

\section{Figure 10}

A representative diagram of study handling and cell treatment. 